\title{
Short comment on Chironomidae (Insecta: Diptera) from Brazil's Federal District
}

\author{
Kathia Cristhina Sonoda
}

Embrapa Meio Ambiente. Rod SP 340. Km 127.5. CEP 13918-110, Jguariúna, SP, Brazil

E-mail: kathia.sonoda@embrapa.br

\begin{abstract}
There is much left to learn about the diversity of Chironomidae in Brazil. To help to resolve this problem, a preliminary study of the Chironomidae present in a stream located in center of Brazil was proposed. The aim of this research was to provide a first record of the Chironomidae assemblage at Sarandi stream, in the Brazilian Cerrado. Samples were taken using a handheld D-net from the stream in October 2009. The samples were transported to the laboratory where the material was processed and the Chironomidae specimens were slide mounted, counted and identified to genera. Ninety individuals belonging to 15 genera were found, Chironomini was the richest tribe, with seven genera, while Tanytarsini showed the highest abundance of individuals (55.6\%). Overall, Rheotanytarsus (20\%), Tanytarsus ortoni-group (16.7\%) and Lopescladius (14.4\%) were the most abundant genera.
\end{abstract}

\section{Introduction}

The Brazilian Cerrado biome is a parallel to the African Savannah; it covers $25 \%$ of the core of the Brazilian territory (Carvalho et al. 2009) (Fig. 1) and is considered a hotspot area of biodiversity (Brasil 2006). The biome has a particular and highly significant role in Brazilian aquatic resources since it contributes to the formation of eight out of twelve of Brazil's largest river basins (Lima and Silva 2008). Estimates indicate there are 6,000 species of trees and 800 of birds. In the last decades, the Cerrado has been seen as an alternative to the Amazonian region for agriculture purposes (MMA 2007); aside from agricultural use, up to 60\% of the biome is preserved (Sano et al. 2001).

Although the biology and ecology of the Chironomidae in some of the Brazilian biomes has been extensively studied (Sanseverino and Nessimian 2008, Silva et al. 2009), the composition of the aquatic entomofauna in a great part of the Cerrado remains unclear. The limited knowledge in chironomid biodiversity is not necessarily due to lack of research conducted within the Cerrado, but rather the extensive area that the biome occupies. Additionally, few focus exclusively on Chironomidae (Sonoda et al. 2009a, Sonoda et al. 2009b, Saito and Fonseca-Gessner 2014, Mazão et al. 2016). When considering the Federal District region, we notice that most studies analyze the entire aquatic entomofauna and the influence of human activities on

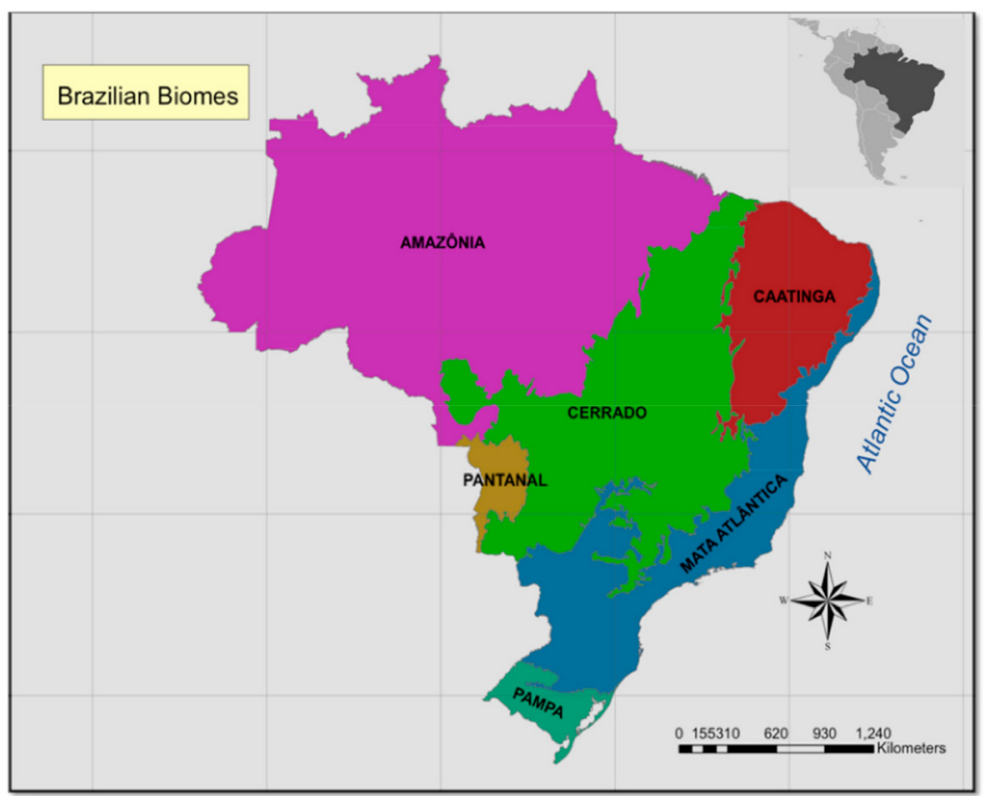

Figure 1. Map of Brazilian Biomes, Cerrado in green. From Merrick et al. (2019). 
it (Silva 2007); there are few gray studies available focusing on the chironomid fauna in the Federal District in which results were not published.

While many studies registered Brazil's chironomid fauna (Oliveira and Laurindo 2011, Floss et al. 2012, De Toni et al. 2014), it is believed that only a small fraction of members of the family inhabiting aquatic ecosystems from the Neotropical Region have been described and recognized (Armitage et al. 1995, Spies and Reiss 1996, Ferrington 2008). The last update of the taxonomic catalogue of Brazilian fauna (MMA 2021) registered 632 species in Brazil, comprising 100 genera. Fittkau's remarkable Amazonian survey registered 200 species and stated that there are at least 1,000 species in the region (Fittkau 2001), illustrating the urgent need for Chironomidae biodiversity surveys.

Knowledge of the taxonomic composition of Brazilian fauna will provide key information for managers in charge of developing and maintaining conservation areas (Romero 2009) and is an additional step in the direction towards understanding the role of these aquatic organisms that play a major role in biological monitoring programs (Vondracek et al. 2005, Rodrigues et al. 2019).

The aim of this study is to provide an overview of the taxonomic composition of Chironomidae in a stream within Brazil's Federal district. Ultimately, this will improve the knowledge of Brazil's chironomid fauna.

\section{Material and methods}

The Sarandi stream spring is located in the Embrapa Cerrados compound (Planaltina-DF) and it runs towards the Mestre d'Armas River in the Paraná River Basin (Martins et al. 2002). At the sampling reach $\left(15^{\circ} 35^{\prime} 41.5^{\prime \prime} \mathrm{S}\right.$ and $\left.47^{\circ} 44^{\prime} 45.3^{\prime \prime} \mathrm{W}\right)$ there were rapids, waterfalls and pools and the stream sediment was sandy with interspersed gravel and cobbles. Deposits of decaying leaves from the abundant riparian vegetation were found throughout the stream bottom.

The climate in the study region is tropical with marked hydrological periods, rainfall is concentrated from November to January and the drought period occurs mostly between June and August (Carvalho 2005). Sampling occurred before the beginning of the rainy season, in October 2009.

Chemical and physical variables of water were analyzed in field (temperature, $\mathrm{pH}$, dissolved oxygen, conductivity) using a portable multiparameter device (Hanna HI 93703) and in the laboratory (nitrite, nitrate, ammonium, phosphate, fluoride, magnesium) using ionic chromatography (Compact IC 761) and UV spectrophotometry to measure total phosphorus (APHA 1998). A handheld D-net was used for sampling (0.2 $\mathrm{mm}$ mesh size); two replicates of 5 minutes each were taken from different habitats along the stream reach. The samples were transported to the laboratory where each sample was washed under running water over a $0.2 \mathrm{~mm}$ mesh sieve (Trivinho-Strixino and Strixino 1998). The material retained within the sieve was placed in clear plastic trays over a trans-illumination device and insects were sorted and preserved in $70 \%$ alcohol (Pinder 1989). The Chironomidae larvae were slide mounted, counted, and identified to genera following Trivinho-Strixino and Strixino (1995).

The community was analyzed both as raw numbers and percentage of individuals per genus. McIntosh's diversity (McIntosh 1967), Margalef's richness and McIntosh's evenness (calculated considering McIntosh diversity) were calculated. The formulae are presented below:

$$
\begin{array}{ll}
\text { Margalef's Richness: } \mathrm{D}=(\mathrm{S}-1) / \log \mathrm{N} & \text { equation 1 } \\
\text { McIntosh's Evenness: } \mathrm{E}=(\mathrm{N}-\mathrm{U}) /[\mathrm{N}-(\mathrm{N} / \sqrt{ } \mathrm{S})] & \text { equation 2 } \\
\mathrm{U}=\sqrt{ } \sum\left(\mathrm{n}_{\mathrm{i}}\right)^{2} & \text { equation 3 } \\
\text { McIntosh's Diversity: } \mathrm{D}=(\mathrm{N}-\mathrm{U}) /(\mathrm{N}-\sqrt{ } \mathrm{N}) & \text { equation 4 }
\end{array}
$$

Where $\mathrm{n}=$ number of individuals from each taxon, $\mathrm{N}=$ total number of individuals, $\mathrm{S}=$ number of taxa.

McIntosh (1967) proposed equation 3, however it is extremely influenced by the sample size. Afterwards, Pielou (1969) proposed equation 4 to eliminate the negative effect of the sample size. We opted to use McIntosh's index because it better suits samples with smaller sizes as it squares abundance and also dominant taxa are weighted greater than rare ones (Semensatto Jr. 2003).

Evenness values range from 0 and 1, values closer to 1 suggest better distribution/participation among taxa. 


\section{Results}

Ninety Chironomidae larvae were collected from the Sarandi stream, comprising 15 genera (Table 1). Chironomini was the most abundant tribe with seven genera, whereas Tanytarsini had a higher abundance of individuals (55.6\%). Three Orthocladiini genera were present and accounted for $25.6 \%$ individuals of the entire community. Pentaneurini was present with only one genus and in low quantity.

Table 1. List of genera and corresponding percent abundance collected at the Sarandi stream.

\begin{tabular}{ll}
\hline Taxon & Percentage \\
\hline Chironomini & 2.2 \\
Beardius Reiss \& Sublette, 1985 & 7.8 \\
Endotribelos Grodhaus, 1987 & 4.4 \\
Lauterborniella Thienemann \& Bause, 1913 & 4.4 \\
Nimbocera Reiss, 1972 & 4.4 \\
Polypedilum Kieffer, 1912 & 1.1 \\
Stenochironomus Kieffer, 1919 & \\
Tanytarsini & 16.7 \\
Tanytarsus ortoni-group Lin et al., 2018 & 1.1 \\
Constempellina Brundin, 1947 & 20.0 \\
Rheotanytarsus Thienemann \& Bause, 1913 & 3.3 \\
Stempellina Thienemann \& Bause, 1913 & 7.8 \\
Tanytarsini \#1 (unknown) & \\
Orthocladiini & 7.8 \\
Corynoneura Winnertz, 1846 & 14.4 \\
Lopescladius Oliveira, 1967 & 3.3 \\
Nanocladius Kieffer, 1913 & \\
Pentaneurini & \\
Thienemannimyia Fittkau, 1957 & 1.1 \\
\hline
\end{tabular}

The most numerous genera were Rheotanytarsus which were the most abundant $(20.0 \%)$, followed by the Tanytarsus ortoni-group (16.7\%) and Lopescladius (14.4\%). The T. ortoni-group contains species previously placed in Caladomyia Säwedal, 1981 (Lin et al. 2018). Corynoneura, Endotribelos and Tanytarsini \#1 each represented $7.8 \%$ of the total taxa. Tanytarsini \#1 did not resemble a known genus and it most likely represents a new species. Three genera, Constempellina, Stenochironomus and Thienemannimyia, were found in extremely low numbers, with one individual each (Table 1). We attempted to rear larvae of Constempellina to the adult stage, however this was unsuccessful. Our observations showed that these larvae are quite sensitive and die only a few minutes after they are taken from the stream.

Indices values were as follows: McIntosh's diversity =0.7; Margalef's richness $=2.2$; McIntosh's evenness $(\mathrm{U})=0.9$. Water quality values registered during sampling are given in Table 2 .

\section{Discussion}

Some studies on the Brazilian Federal District consider the entire aquatic insects' communities, nonetheless they identify the Chironomidae larvae only to family. This type of analysis certainly decreases the time required to execute environmental studies since identification of Chironomidae to genera is time consum-

Table 2. Water quality variable values at the sampling reach of the Sarandi stream.

\begin{tabular}{l|l}
\hline Water variable & Value \\
\hline $\mathrm{pH}$ & 4.5 \\
Conductivity $(\mu \mathrm{S} / \mathrm{cm})$ & 6.0 \\
Temperature $\left({ }^{\circ} \mathrm{C}\right)$ & 21.7 \\
Dissolved oxygen $(\mathrm{mg} / \mathrm{L})$ & 7.3 \\
$\mathrm{Cl}(\mathrm{mg} / \mathrm{L})$ & 0.23 \\
$\mathrm{Na}(\mathrm{mg} / \mathrm{L})$ & 0.23 \\
$\mathrm{Ca}(\mathrm{mg} / \mathrm{L})$ & 0.44 \\
Fluoride & 0.00 \\
Nitrate & 0.00 \\
Magnesium & 0.00 \\
\hline
\end{tabular}


ing; however significant information is lost, such as the taxonomic composition, functional feeding groups, among others. In this context, a study of the same watershed examined the aquatic macroinvertebrates community composition along the Mestre d'Armas River (Silva 2007). The Chironomidae were identified to subfamily which severely limits accurate comparison with our data. They also recorded low $\mathrm{pH}$ levels, and this seems to be a constant among other rivers in this part of the Cerrado (Salcedo 2006, Fernandes 2007).

As the Cerrado is a biodiversity hotspot (Hopper et al. 2016), we expected to find higher taxa richness - this would certainly be the case if more streams were sampled. Fernandes (2007) conducted a study at a different stream in the same region, and registered nine taxa, eight of which were not found in our study. Combining taxa from our study and that of Fernandes (2007) yields a total of 24 taxa, increasing the richness.

Studies from other Cerrado regions have yielded higher generic richness, with 45 genera found at the State of Goiás (Mazão and Bispo 2016) and 36 at São Paulo State (Saito and Fonseca-Gessner 2014). This supports our suggestion that the true richness value in the Federal District is likely much higher than presented here.

Rheotanytarsus was documented as one of the most abundant taxa in several Brazilian studies (Sonoda et al. 2009b, Sonoda et al. 2010, Floss et al. 2012); this numerical dominance is related to agricultural land use (Sonoda et al. 2009a, Sonoda et al. 2018). Its abundance is also documented in other neotropical countries, like Trinidad (Helson et al. 2006).

At the other extreme, we found multiple rare genera, Constempellina, Stenochironomus and Thienemannimyia, which contributed with only one specimen for each genus. These genera usually are associated with good environmental conditions (Eintrekin et al. 2007, Saito and Fonseca-Gessner 2014). The abundance of Stenochironomus in Neotropical streams is quite variable as some authors report their rarity (Gonçalves Jr et al. 2007), while others have documented great abundances of this genus (Saito and Fonseca-Gessner 2014, Mazão and Bispo 2016). Stenochironomus larvae are important indicators for the preservation status of riparian forests, as they are known as shredders (Silva et al. 2009, Santos and Rodrigues 2015). Despite the low quantity of shredders in Neotropical communities (Boyero et al. 2011), they are good indicators of environmental impacts since their abundance decreases when riparian forests are deforestated (Sonoda et al. 2009a).

\section{Conclusion and outlook}

The present report of Chironomidae in the Federal District provides critical information to the scientific community that enhances the understanding of chironomid diversity within the Cerrado and provides evidence that continued efforts should be made to add information to this list, ultimately enhancing our knowledge of the spatial occurrence and elucidating the dimensions of biodiversity richness of the Chironomidae.

Several questions remain unanswered and should be addressed in future work, such as including local seasonality patterns for specific chironomid genera, influence of the weather, hydrology and other environmental attributes, and the family's influence on litter decomposition process.

\section{Acknowledgments}

Thanks to Daphne Muniz for field procedures and Margit Bergener Leite Guimarães for English revisions. I gratefully acknowledge the anonymous referee who contributed with substantial criticism that improved the text.

\section{References}

APHA - American Public Health Association. 1998. Standard methods for the examination of water and wastewater. e. 20.

Armitage, P.D., Cranston, P.S. and Pinder, L.C.V. (Eds.) 1995. The Chironomidae, biology and ecology of non-biting midges. Chapman \& Hall. $800 \mathrm{p}$.

Boyero, L., Pearson, R.G., Dudgeon, D., Graça, M.A.F., Gessner, M.O., Albarino, R.J., Ferreira, V., Yule, C.M., Boulton, A.J., Arunachalan, M., Callisto, M., Chauvet, E., Ramirez, A., Chará. J., Moretti, M.S., Júnior, J.F.G., Helson, J.E., Chará-Serna, A.M., Encalada, A.C., Davids, J.N., Cornejo, A., Li, A.O.Y., Buria, L.M., Villanueva, V.D., Zuniga, M.C. and Pringle, C.M. 2011. Global distribution of a key trophic guild contrasts with common latitudinal diversity patterns. - Ecology 92(9):1839-1848. DOI: https:// doi.org/10.1890/10-2244.1 
Brasil. 2006. Ministério do Meio Ambiente. Secretaria de Biodiversidade e Florestas. Núcleo dos Biomas Cerrado e Pantanal. Programa Nacional de Conservação e uso sustentável do bioma cerrado. 67 p. (In Portuguese).

Carvalho, F.M.V., De Marco Júnior, P. and Ferreira, L.G. 2009. The Cerrado into-pieces: habitat fragmentation as a function of landscape use in the savannas of central Brazil. - Biological Conservation 142: 1392-1403. DOI: https://doi.org/10.1016/j.biocon.2009.01.031

Carvalho, P.R.S. 2005. A expansão urbana na bacia do ribeirão Mestre d'Armas (DF) e a qualidade da água. - Estudos geográficos 3(1): 71-91. (In Portuguese)

De Toni, K.R., Nava, D., Restello, R.M., Decian, V., Rovani, I.L. and Hepp, L.U. 2014. Integridade da paisagem e sua influência sobre a composição da comunidade de Chironomidae (Diptera) em riachos de pequena ordem. - Ecologia Austral, 24: 335-342. (In Portuguese)

Eintrekin, S.A., Wallace, J.B. and Eggert, S.L. 2007. The response of Chironomidae (Diptera) to a longterm exclusion of terrestrial organic matter. - Hydrobiologia 575: 401-413. DOI: https://doi.org/10.1007/ s10750-006-0386-7

Fernandes, A.C.M. 2007. Macroinvertebrados bentônicos como indicadores biológicos de qualidade da água: proposta para elaboração de um índice de integridade biológica. $\mathrm{Ph} . \mathrm{D}$, Thesis. Universidade de Brasília, Brasília, Distrito Federal. 226p. (In Portuguese)

Ferrington, L.C. 2008. Global diversity of non-biting midges (Chironomidae; Insecta-Diptera) in freshwater. - Hydrobiologia 595:447-455. DOI: https://doi.org/10.1007/s10750-007-9130-1

Fittkau, E.J. 2001. Amazonian Chironomidae (Diptera, Chironomidae): A contribution to chironomid research in the neotropics. - Amazoniana-Limnologia et Oecologia Regionalis Systemae Fluminis Amazonas 16(3-4): 313-323.

Floss, E.C.S., Kotzian, C.B., Spies, M.R. and Secretti, E. 2012. Diversity of non-biting midge larvae assemblages in the Jacuí River basin, Brazil. - Journal of Insect Science, 12: 121. www.insectscience. org/12.121

Gonçalves Jr, J.F., Graça, M.A.S. and Callisto, M. 2007. Litter decomposition in a Cerrado savannah stream is retarded by leaf toughness, low dissolved nutrients and a low density of shredders. - Freshwater Biology 52: 1440-1451. DOI: https://doi.org/10.1111/j.1365-2427.2007.01769.x

Helson, J.E., Williams, D.D. and Turner, D. 2006. Larval chironomid community organization in four tropical rivers: human impacts and longitudinal zonation. - Hydrobiologia 559: 413-431. DOI: https://doi. org/10.1007/s10750-005-0977-8

Hopper, S.D., Silveira, F.A.O. and Fiedler, P.L. 2016. Biodiversity hotspots and Ocbil theory. - Plant Soil 403: 167-216. DOI: https://doi.org/10.1007/s11104-015-2764-2

Lima, J.E.F.W. and Silva, E.M. 2008. Recursos hídrico do bioma Cerrado. In Sano, S.M., Almeida, S.P., Ribeiro, J.F. (Eds.). Cerrado: ecologia e flora. Embrapa Cerrados, Brasília, Distrito Federal. pp. 90106. $2^{\text {nd }}$ ed. v.1. (In Portuguese)

Lin, X.-L., Stur, E. and Ekrem, T. 2018. Molecular phylogeny and temporal diversification of Tanytarsus van der Wulp (Diptera: Chironomidae) support generic synonymies, a new classification and centre of origin. - Systematic Entomology 43: 659-677. https://doi.org/10.1111/syen.12292

Martins, E.S., Reatto, A., Farias, M.R., Valverde, A.A., Bloise, G.L.F., Cardoso, E.A., Spera, S.T., Carvalho Jr, A.O. and Guimarães, R.F. 2002. Domínios hidrogeológicos da margem direita do córrego Divisa, Bacia do São Bartolomeu-DF, escala 1:10.000. Embrapa Cerrados, Brasília, Distrito Federal. 17p. (In Portuguese)

Mazão, G.R. and Bispo, P.C. 2016. The influence of physical instream spatial variability on Chironomidae (Diptera) assemblages in Neotropical streams. - Limnologica, 60: 1-5. DOI: https://doi.org/10.1016/j. $\underline{\text { limno.2016.03.004 }}$

Merrick, T., Pau, S., Jorge, M.L.S.P., Silva, T.S.F., Bennartz, R. 2019. Spatiotemporal Patterns and Phenology of Tropical Vegetation Solar-Induced Chlorophyll Fluorescence across Brazilian Biomes Using Satellite Observations. - Remote Sensing 11, 1746. DOI: https://doi.org/10.3390/rs11151746 
McIntosh, R.P. 1967. An index of diversity and the relations of certain concepts of diversity. - Ecology, 48: 392-404.

MMA - Ministério do Meio Ambiente. 2007. Biodiversidade do Cerrado e Pantanal: áreas e ações prioritárias para conservação. Ministério do Meio Ambiente. 540 p. (Série Biodiversidade 17). (In Portuguese)

MMA - Ministério do Meio Ambiente. 2021. Taxonomic Catalogue of Brazilian Fauna. http://fauna.jbrj. gov.br/fauna/listaBrasil/

Oliveira, C.S.N. and Laurindo, F.S. 2011. Two new species of Larsia Fittkau, 1962 (Diptera: Chironomidae: Tanypodinae) from Neotropical Region, with a checklist of Larsia species of the world. - Zootaxa 2786: 27-41. DOI: https://doi.org/10.15468/k7mcu7

Pielou, E.C. 1969. An Introduction to Mathematical Ecology. Wiley-Interscience. 279p.

Pinder, L.C.V. 1989. The adult males of Chironomidae (Diptera) of the Holartic region. Introduction. - Entomologica scand. suppl. 34: 5-9.

Rodrigues, C., Guimarães, L. and Vieira, N. 2019. Combining biomarker and community approaches using benthic macroinvertebrates can improve the assessment of the ecological status of rivers. - Hydrobiologia 839: 1-24. DOI: https://doi.org/10.1007/s10750-019-03991-7

Romero, T. 2009. Biota e políticas públicas. http://www.agencia.fapesp.br/materia/10083/especiais/biotae-politicas-publicas.htm (In Portuguese)

Salcedo, A.K.M. 2006. Variação temporal e espacial e importância ecológica de macroinvertebrados aquáticos num córrego periurbano do Distrito Federal. Ms.C. Dissertation. Universidade de Brasília, Brasília, Distrito Federal. 71p. (In Portuguese)

Santos, I.G.A. and Rodrigues, G.G. 2015. Colonização de macroinvertebrados bentônicos em detritos foliares em um riacho de primeira ordem na Floresta Atlântica do nordeste brasileiro. - Iheringia, Série Zoologia 105(1):84-93. DOI: https://doi.org/10.1590/1678-4766201510518493 (In Portuguese)

Saito, V.S. and Fonseca-Gessner, A.A. 2014. Taxonomic composition and feeding habits of Chironomidae in Cerrado streams (Southeast Brazil): impacts of land use changes. - Acta Limnologica Brasiliensia 26(1): 35-46. DOI: https://doi.org/10.1590/S2179-975X2014000100006

Sano, E.E., Jesus, E.T. and Bezerra, H.S. 2001. Uso de um sistema de informações geográficas para quantificação de áreas remanescentes do Cerrado. Embrapa Cerrados, Brasília, Distrito Federal. 4p. (In Portuguese)

Sanseverino, A.M. and Nessimian, J.L. 2008. Larvas de Chironomidae (Diptera) em depósitos de folhiço submerso em um riacho de primeira ordem da Mata Atlântica (Rio de Janeiro, Brasil). - Revista Brasileira de Entomologia 52(1): 95-104. DOI: https://doi.org/10.1590/S0085-56262008000100017 (In Portuguese)

Semensatto Jr, D.L. 2003. Aplicação de índices de diversidade em estudos envolvendo associações entre foraminíferos e tecamebas recentes: uma breve discussão. In Annals of the Congresso da Associação Brasileira de Estudos do Quaternário, 9. CD-ROM, 1: 1-5. (In Portuguese)

Silva, F.L., Pauleto, G.M., Talamoni, J.L.B. and Ruiz, S.S. 2009. Categorização funcional trófica das comunidades de macroinvertebrados de dois reservatórios na região Centro-Oeste do Estado de São Paulo, Brasil. - Acta Scientiarum, Biological Sciences 31(1):73-78. (In Portuguese)

Silva, N.T.C. 2007. Macroinvertebrados bentônicos em áreas com diferentes graus de preservação ambiental na Bacia do Ribeirão Mestre d'Armas, DF. Ms.C. Dissertation. Universidade de Brasília, Brasília, Distrito Federal. 99p. (In Portuguese)

Sonoda, K.C., Matthaei, C.D. and Trivinho-Strixino, S. 2009a. Contrasting land uses affect Chironomidae communities in two Brazilian rivers. - Fundamental and Applied Limnology/Archiv für Hydrobiologie 174(2): 173-184. DOI: https://doi.org/10.4081/jlimnol.2018.1799

Sonoda, K.C., Malaquias, J. and Vettorazzi, C. 2009b. Chironomidae (Insecta, Diptera) from Alto Paranapanema Basin, Southeastern Brazil. - CHIRONOMUS Newsletter on Chironomidae research 23: 25-32. DOI: https://doi.org/10.5324/cjcr.v0i23.662 
Sonoda, K.C., Ortega, E.M.W., Vettorazzi, C. and Trivinho-Strixino, S. 2010. Chironomidae assemblage from four Brazilian watersheds under different anthropogenic pressure. In Annals of the 1 $7^{\text {th }}$ International Symposium on Chironomidae. Tianjin, Nakai University, China.

Sonoda, K.C., Monteles, J.S., Ferreira, A. and Gerhard, P. 2018. Chironomidae from Eastern Amazon: Understanding the differences of land-use on functional feeding groups. - Journal of Limnology 77(s1): 196-202. DOI: https://doi.org/10.4081/jlimnol.2018.1799

Spies, M. and Reiss, F. 1996. Catalog and bibliography of Neotropical and Mexican Chironomidae (Insecta, Diptera). - Spixiana Supplement 22:61-119

Trivinho-Strixino, S. and Strixino, G. 1995. Larvas de Chironomidae (Diptera) do Estado de São Paulo: guia de identificação e diagnose dos gêneros. 230 p. (In Portuguese)

Trivinho-Strixino, S. and Strixino, G. 1998. Chironomidae (Diptera) associados a troncos de árvores submersos. - Revista Brasileira de Entomologia 41(2-4): 173-178. (In Portuguese)

Vondracek, B., Blann, K.L., Cox, C.B., Nerbonne, J.F., Mumford, K.G., Berbonne, B.A., Sovell, L.A. and Zimmerman, J.K.H. 2005. Land use, spatial scale, and stream systems: lessons from an agricultural region. - Environmental Management 36(6): 775-791. DOI: https://doi.org/10.1007/s00267-005-0039-z

Article submitted 15. December 2020, accepted by Alyssa M. Anderson 12. February 2021, published 1. March 2021. 